\title{
Sorologia positiva para Leptospira butembo em bovinos apresentando problemas reprodutivos
}

\author{
Positive serology for Leptospira butembo in bovine with reproductive problems
}

\author{
Guilherme Bastos Saldanha' ${ }^{\mathrm{I}}$ Neimar Cristiano Cavazini ${ }^{\mathrm{I}}$ \\ Aleksandro Schafer da Silva ${ }^{\mathrm{I}}$ Mariana Bertini Fernandes ${ }^{\mathrm{I}}$ \\ Manoel Renato Teles Badke ${ }^{\text {II }}$ \\ Cristian Gilberto Pivetta ${ }^{\text {III }}$
}

\begin{abstract}
O objetivo deste trabalho foi relatar um surto de infertilidade em vacas leiteiras de uma propriedade no Estado de Santa Catarina, que pode ter sido causado por Leptospira butembo. Foram utilizados 11 sorovares de Leptospira para testar 13 amostras de soro de fêmeas bovinas com a finalidade de realizar o diagnóstico por soroaglutinação microscópica (MAT). Observou-se que todos os animais reagiram com o sorovar L. butembo com títulos entre 100 e 800 . Após tratamento com sulfato de estreptomicina, verificou-se que 92\% dos animais voltaram à vida reprodutiva normal. Com base nestes resultados, conclui-se que $\mathbf{L}$. butembo pode ter sido a causa do problema reprodutivo dos bovinos.
\end{abstract}

Palavras-chave: Leptospira butembo, bovino, problemas reprodutivos.

\section{ABSTRACT}

This research was aimed at reporting an outbreak of infertility in milking cows at a farm in the state of Santa Catarina, Brazil, that could be caused by Leptospira butembo. Eleven serovars of Leptospira were used for testing 13 cow serum samples against leptospirosis by using the microscopic agglutination test (MAT). All serum samples of the animals reacted with $\mathbf{L}$. butembo serovar with titles between 100 and 800. After treatment with streptomycin sulfate, $92 \%$ of the animals returned to reproductive life. These results suggest that L.butembo may have been responsible for the bovines reproductive problems.

Key words: Leptospira butembo, bovine, reproductive problems.
Bactérias do gênero Leptospira possuem diversos sorovares patogênicos para homens e animais. Na classificação sorológica, os sorovares constituem a unidade taxonômica e são definidos por reações de aglutinação após adsorção dos soros com antígenos homólogos. Existem cerca de 200 sorovares identificados que, devido às semelhanças antigênicas entre si, estão agrupados em sorogrupos (LEVETT, 2001).

As perdas econômicas produzidas pela leptospirose estão diretamente ou indiretamente relacionadas a custos com assistência veterinária, medicamentos, vacinas, testes laboratoriais, falhas reprodutivas e aborto. Os problemas reprodutivos são as principais manifestações clínicas da leptospirose crônica em fêmeas bovinas, sendo freqüentemente os únicos sinais observados no rebanho (FAINE, 1999).

Em bovinos, o sorovar hardjo é o mais importante porque compromete o desempenho reprodutivo dos rebanhos acometidos, causando abortamento, natimortalidade e nascimento de bezerros fracos (LILENBAUM, 1996). A ocorrência de infecções incidentais, causadas por sorovares que não são mantidos nos bovinos, como australis, bratislava, butembo, castellonis, grippotyphosa, copenhageni, panama, pyrogenes, shermani, andamana e patoc,

ICurso de Medicina Veterinária, Universidade Federal de Santa Maria (UFSM), Santa Maria, RS, Brasil.

IIDepartamento de Microbiologia e Parasitologia, Centro de Ciência da Saúde (CCS), UFSM. Faixa de Camobi, km 9, prédio 20, sala 4235, 97105-900, Santa Maria, RS, Brasil. E-mail: mrenato2004@yahoo.com.br. Autor para correspondência.

IIICooperativa Agropecuária, São Lourenço do Oeste, Santa Catarina, Brasil. 
deve-se ao contágio indireto, pois animais mantidos a pasto têm acesso livre a lagoas, banhados e matas ciliares, onde existem animais silvestres e roedores que podem atuar como portadores e transmitir esses sorovares para os bovinos (LILENBAUM, 1996). O objetivo deste trabalho foi relatar um surto de infertilidade em vacas leiteiras, positivas para Leptospira butembo, em uma propriedade de Santa Catarina.

Foram analisadas 13 amostras de soro de vacas leiteiras, provenientes de uma propriedade rural do município de São Lourenço D’Oeste - SC, com a finalidade de realizar o diagnóstico sorológico de leptospirose bovina, devido a estes animais apresentarem altas taxas de retorno ao cio.

Os testes foram realizados no Setor de Leptospirose da Universidade Federal de Santa Maria, sendo o sangue centrifugado e o soro submetido posteriormente à diluição de 1/100 com solução de Sorensen, sendo testado com 11 sorovares de Leptospira. Os soros que reagiram na diluição 1/100 foram considerados positivos, sendo então diluídos para determinar o título final. Os sorovares utilizados foram $L$. hardjo, $L$. wolffi, $L$. grippotyphosa, $L$. canicola, L. icterohaemorrhagiae, $L$. australis, $L$. bratislava, L. pomona, L. tarassovi, L. butembo e $L$. castelloni.

A técnica utilizada foi a soroaglutinação microscópica (SAM), que é recomendada pela Organização Mundial de Saúde (MINISTÉRIO DA SAÚDE, 1995; GALTON et al., 1965). Os animais positivos para leptospirose foram tratados com sulfato de estreptomicina, em dose única de $25 \mathrm{mg} \mathrm{kg}^{-1}$, via intramuscular, conforme recomendado por HUHN et al. (1993). Os animais foram inseminados no primeiro cio após tratamento, e o diagnóstico de gestação foi realizado entre 60 e 90 dias de prenhes.

Observaram-se em todos os animais analisados, reações positivas apenas para L. butembo, com títulos entre 100 e 800 . Todas as vacas seriam descartadas pelo proprietário, devido a apresentarem altas taxas de retorno ao cio. Após o tratamento, verificou-se que 12 animais voltaram à vida reprodutiva, isto é, confirmou-se a prenhez através de palpação retal.

HOMEM et al. (2001) realizaram um estudo da soroprevalência de leptospirose em bovinos de propriedades familiares na região de fronteira agrícola da rodovia Transamazônica, na Amazônia Oriental, sendo observada uma freqüência de $1,5 \%$ de $\boldsymbol{L}$. butembo em concomitância com mais quatro sorovares. Prevalências semelhantes foram reportadas por DEL FAVA et al. (2003) e AGUIAR et al. (2006), que observaram a L. butembo em 2 e 0,9\%, respectivamente. Diferentemente dos trabalhos citados anteriormente, neste estudo observou-se a prevalência de $100 \%$ de $\boldsymbol{L}$. butembo em vacas leiteiras, possivelmente devido à contaminação pela urina de roedores, na água e no alimento (ração) fornecidos aos animais da propriedade, em virtude do livre acesso de ratos ao ambiente.

LILENBAUM (1996) considera a $\boldsymbol{L}$. butembo em bovinos um caso incidental, porque possivelmente a transmissão ocorra devido ao contato direto dos animais com ambientes contaminados pela Leptospira oriunda de roedores e animais silvestres. Conforme TIMONEY et al. (1988) e PRESCOTT (1993), leptospiras podem sobreviver durante vários dias no ambiente com temperatura elevada, umidade, $\mathrm{pH}$ neutro ou ligeiramente alcalino e com presença de matéria orgânica. O ambiente onde as vacas se encontravam apresentava grande parte das características citadas acima, tornando-o favorável à sobrevivência da bactéria.

No presente estudo, observou-se a eficácia do sulfato de estreptomicina no controle de leptospirose, visto que $92 \%$ das vacas voltaram à vida reprodutiva normal após tratamento. A estreptomicina é o medicamento mais indicado no combate à leptospirose, pois apresenta fácil penetração renal, destruindo as leptospiras presentes nos túbulos renais (GERRITSEN et al., 1994).

L. butembo causa infertilidade em bovinos, por esse motivo, sugere-se a inclusão desse sorovar nas vacinas comercias presentes no mercado brasileiro. O tratamento com sulfato de estreptomicina foi eficaz no tratamento da leptospirose.

\section{REFERÊNCIAS}

AGUIAR, D.M. et al. Seroprevalence of Leptospira sp. in cattle from Monte Negromunicipality, western Amazon. Pesquisa Veterinária Brasileira, v.26, n.2, p.102-104, 2006.

DEL FAVA, C. et al. Manejo sanitário para o controle de doenças da reprodução em um sistema leiteiro de produção semi-intensivo. Arquivos do Instituto Biológico, v.70, n.1, p.25-33, 2003.

FAINE, S. Leptospira and leptospirosis. Melbourne: MedSci, 1999. 353p.

GALTON, M.M. et al. Application of a microtechnique to the agglutination test for leptospiral antibodies. Applied Microbiology, v.13, n.1, p.81-5, 1965.

GERRITSEN, M.J. et al. Effective treatment with dihydroestreptomycin of naturally infected cows shedding Leptospira interrogans serovar hardjo subtype hardjobovis. 
American Journal of Veterinary Research, v.55, n.3, p.339-343, 1994.

HOMEM, V.S.F. et al. Estudo epidemiológico da leptospirose bovina e humana na Amazônia oriental brasileira. Revista da Sociedade Brasileira de Medicina Tropical, v.34, n.2, p.173-180, 2001.

HUHN, R. G. et al. Immunity to Leptospirosis: Leptospira interrogans serotype pomona bacterins in cattle. American Journal of Veterinary Research, v.36, p.59-65, 1993.

LEVETT, P.N. Leptospirosis. Clinical Microbiology Reviews, v.14, p.296-326, 2001.
LILENBAUM, W. Atualização em leptospiroses bovinas. Revista Brasileira Medicina Veterinária, v.18, n.1, p.913, 1996.

MINISTERIO DA SAUDE. Fundação Nacional da Saúde: manual de leptospirose. Brasília, 1995. 97p.

PRESCOTT J.F. Leptospirosis. In: JUBB K.V.F. et al. (Eds). Pathology of domestic animals. 4.ed. San Diego: Academic, 1993. p.503-511.

TIMONEY J.F. et al. The spirochetes. In: HAGAN W.A.; BRUNER'S, D.W. Microbiology and infectious diseases of domestic animals. 8.ed. Ithaca, USA: Comstock, 1988. p.45-57. 